\title{
Aspartate Aminotransferase in Alfalfa Nodules: Localization of mRNA During Effective and Ineffective Nodule Development and Promoter Analysis
}

\author{
Hirofumi Yoshioka, ${ }^{1,2}$ Robert G. Gregerson, ${ }^{3}$ Deborah A. Samac, ${ }^{4,5}$ Kim C. M. Hoevens, ${ }^{6}$ \\ Gian Trepp, ${ }^{1,7}$ J. Stephen Gantt, ${ }^{8}$ and Carroll P. Vance ${ }^{1,4}$ \\ ${ }^{1}$ Department of Agronomy and Plant Genetics, University of Minnesota, St. Paul 55108, U.S.A.; ${ }^{2}$ Graduate \\ School of Bioagricultural Sciences, Nagoya University, Chikusa, Nagoya 464-8601, Japan; ${ }^{3}$ Department \\ of Biology, Lyon College, Batesville, AR 72503, U.S.A.; ${ }^{4}$ U.S. Department of Agriculture, Agricultural \\ Research Service, Plant Science Research Unit, St. Paul, MN 55108, U.S.A.; ${ }^{5}$ Department of Plant \\ Pathology, University of Minnesota, St. Paul 55108, U.S.A.; ${ }^{6}$ Higher Institute for Professional Education \\ Venlo, Division Laboratory Science, 3-Decembersingel 36, 5822 BD Venlo, The Netherlands; ${ }^{7}$ Institut fuer \\ Pflauzenwissenschaften ETH-Zurich, 8092 Zurich, Switzerland; ${ }^{8}$ Department of Plant Biology, University \\ of Minnesota, St. Paul 55108, U.S.A.
}

Accepted 15 December 1998.

\begin{abstract}
Aspartate aminotransferase (AAT) plays a critical role in the assimilation of symbiotically fixed nitrogen into aspartate and asparagine in legume root nodules. The enzyme occurs as a cytosolic form (AAT1) and a plastid form (AAT2) in alfalfa nodules. To elucidate the functional role of each isozyme in root nodule metabolism further, in situ hybridization was used to determine the pattern of transcript accumulation from the two genes. AAT2 transcripts were localized to infected cells throughout the symbiotic zone of effective alfalfa nodules; however, expression was reduced in ineffective nodules. The AAT1 gene was expressed in the uninfected cells of the invasion zone and symbiotic zone, the nodule parenchyma, and nodule vascular bundles of both effective and ineffective nodules. The AAT1 and AAT2 promoters were evaluated in transgenic alfalfa plants containing promoter $\beta$-glucuronidase (GUS) gene fusions. Histochemical staining patterns agreed with results from in situ localization. The distribution pattern of gene transcripts suggests that AAT1 has a role in maintenance of the $\mathrm{O}_{2}$ diffusion barrier in nodules and that AAT2 plays a major role in assimilation of recently fixed nitrogen. Promoter deletion analysis of the AAT2 promoter revealed that nodule-specific expression was retained in a promoter fragment of $\mathbf{3 0 0} \mathbf{b p}$.
\end{abstract}

Additional keywords: malate dehydrogenase, Medicago sativa, nitrogen fixation, phosphoenolpyruvate carboxylase, Sinorhizobium meliloti.

Aspartate aminotransferase (AAT; EC 2.6.1.1) is ubiquitous in both prokaryotes and eukaryotes and has a crucial role in

Corresponding author: Deborah A. Samac

E-mail: debbys@puccini.crl.umn.edu

This article is in the public domain and not copyrightable. It may be freely reprinted with customary crediting of the source. The American Phytopathological Society, 1999. both $\mathrm{C}$ and $\mathrm{N}$ metabolism. The enzyme catalyzes the reversible transfer of the amino group from glutamate to oxaloacetate, yielding 2-oxoglutarate and aspartate. In plants, AAT is involved in many metabolic pathways: the synthesis of aspartate and asparagine for nitrogen transport to the shoot, for protein and amino acid synthesis, and organic acid synthesis to support rhizobial and/or host plant respiration; the assimilation of ammonia in the glutamine synthetase/glutamate synthase (GS/GOGAT) cycle (Ryan and Fottrell 1974), including assimilation of symbiotically fixed nitrogen in legume root nodules (Schubert 1986); and the transfer of fixed carbon from mesophyll cells to bundle sheath cells in a number of $\mathrm{C}_{4}$ plants (Hatch and Mau 1973; Numazawa et al. 1989; Taniguchi and Sugiyama 1990). AAT has also been proposed to play a role in malate-aspartate hydrogen shuttles that distribute reducing equivalents across membranes of chloroplasts, mitochondria, and peroxisomes (Wallsgrove et al. 1983).

Multiple forms of AAT targeted to different subcellular compartments exist in legumes (Boland et al. 1982; Robinson et al. 1994; Wadsworth et al. 1993; Weeden and Marx 1984) and nonlegumes (Liu and Huang 1977; Scandalios et al. 1975; Schultz and Coruzzi 1995; Turano et al. 1991). In alfalfa, AAT is composed of two isozymes, AAT1 and AAT2. AAT1, the cytosolic form, consists predominately of a single isoform of approximately $84 \mathrm{kDa}$ and is found in nodules, roots, stems, and leaves (Griffith and Vance 1989; Robinson et al. 1994). AAT2, localized in plastids, is composed of three isoforms of approximately $80 \mathrm{kDa}$ and is found chiefly in effective root nodules, with lower amounts of enzyme in roots, leaves, and stems (Farnham et al. 1990a; Griffith and Vance 1989; Robinson et al. 1994). Immunoprecipitation studies indicated that approximately $90 \%$ of AAT activity in root nodules is derived from AAT2 (Farnham et al. 1990b). Cellular fractionation and immunogold labeling studies showed that AAT2 protein is localized in chloroplasts of leaves and amyloplasts of cells in root nodules. Labeling of plastids in infected cells was almost four times that of uninfected cells, suggesting that aspartate synthesis in alfalfa root nodules occurs primarily in 
infected cells (Robinson et al. 1994). Although AAT2 is the nodule-enhanced form of AAT in alfalfa, both isoforms occur in the nodule. The specific metabolic roles of AAT1 and AAT2 as well as the cellular expression patterns and regulation of the two genes in root nodules have not been investigated previously.

During alfalfa root nodule development, there is a significant increase in total AAT enzymatic activity (Egli et al. 1989; Gantt et al. 1992; Griffith and Vance 1989), and almost all of this increase in AAT activity can be accounted for by an increase in AAT2 enzyme activity and protein (Farnham et al. 1990a). In young roots from 0 to 4 days after inoculation (DAI), as well as in nodules at 7 and 11 DAI, AAT1 predominates. While AAT2 is not detectable in young roots, by 11 DAI all three AAT2 isoforms are present in nodules, and from 17 to 31 DAI AAT2 is the predominant form of the enzyme (Griffith and Vance 1989). The increase in AAT activity parallels increases in other late nodulins such as glutamate synthase (GOGAT), asparagine synthetase (AS), and phosphoenolpyruvate carboxylase (PEPC). However, maximum AAT activity lags behind acetylene reduction activity (Egli et al. 1989), suggesting that AAT2 regulation is independent of nitrogenase activity.

Experiments with plant-gene-controlled ineffective nodules, ineffective Saranac $\left(\mathrm{in}_{1} \mathrm{Sa}\right)$, support independent regulation of AAT1 and AAT2 in alfalfa nodules. Nodule size and structure of the ineffective genotype closely approximate the effective wild-type nodules, but the ineffective nodules senesce prematurely and exhibit a 95 to $99 \%$ reduction in nitrogenase activity (Egli et al. 1989; Vance and Johnson 1983). Total AAT activity is fivefold greater in mature effective nodules than in ineffective nodules of the same age. During nodule development, the accumulation of AAT2 is similar in effective and ineffective nodules through 9 DAI. However, after this point AAT2 is not detected in ineffective nodules while the enzyme continues to increase in effective nodules. In contrast, AAT1 protein accumulation is similar in effective and ineffective nodules and does not change markedly with nodule development (C. P. Vance and S. S. Miller, unpublished).

cDNA and genomic clones of the alfalfa AAT1 (Gregerson et al. 1994; Udvardi and Kahn 1992) and AAT2 (Gantt et al. 1992; Gregerson et al. 1993, 1994) have been isolated and characterized. The amount of AAT1 and AAT2 mRNA in alfalfa plants is consistent with the corresponding enzyme activity and protein accumulation. AAT1 mRNA is found in nodules, roots, and stems whereas mRNA of AAT2 is most abundant in nodules (Gantt et al. 1992; Gregerson et al. 1994). During effective nodule development, steady-state levels of AAT1-hybridizing mRNA are highest in young nodules and decline with nodule age. Steady-state levels of AAT2 mRNA increase dramatically from undetectable amounts in day 7 nodules to a maximum amount in mature nodules (Gregerson et al. 1994). In ineffective nodules, AAT1 mRNA levels remain relatively constant until nodules become senescent. Samples from all time points contain approximately half the AAT1-hybridizing mRNA found in effective nodules. AAT2 mRNA is more acutely reduced in ineffective plants (Gregerson et al. 1994). Independent regulation of AAT1 and AAT2 genes is also observed in bacterially conditioned ineffective nodules. The accumulation of AAT2 transcripts is dramatically reduced during development of ineffective nodules induced by Sinorhizobium meliloti mutants while the amount of AAT1 mRNA is relatively constant (Vance et al. 1995).

Amino acid comparisons of the deduced AAT1 and AAT2 polypeptides from the genomic clones revealed only 54\% identity between the two genes (Gregerson et al. 1994). Earlier studies showed that antibodies produced against AAT1 and AAT2 are immunologically distinct (Farnham et al. 1990b). Inspection of the sequences $5^{\prime}$ of the translation initiation codon of the AAT2 gene identified two sequence motifs, CTCTT and AAAGAT, that are conserved in several legume nodule-enhanced genes (Gregerson et al. 1994). These sequences may contribute to nodule-enhanced expression of leghemoglobin genes from soybean (Stougaard et al. 1987) and Sesbania rostrata (Metz et al. 1988), the N23 gene from soybean (Jørgensen et al. 1991), the nodulin 20, 22, 23, and 24 genes from soybean (Sandal et al. 1987), and the ENOD2 gene from soybean (Lauridsen et al. 1993). The CTCTT sequence occurs six times upstream of the translation start codon $(-1310,-1050,-1036,-840,-46$, and -16$)$. The AAAGATT motif is present once in this region (-646), as well as three times $(-1130,-871$, and -91$)$ in the inverse orientation (Gregerson et al. 1994). None of these potential cis-acting elements occur in the region upstream of the $A A T 1$ translation initiation codon (Gregerson et al. 1994).

In this study, we examined the spatial and temporal expression of the alfalfa $A A T 1$ and $A A T 2$ genes in effective and ineffective alfalfa root nodules, using in situ hybridization, to understand better the regulation and functional role of these genes. In addition, deletion analysis of the AAT2 promoter was used to determine the effect of sequence motifs in the control of nodule-specific gene expression.

\section{RESULTS}

\section{Localization of AAT2 transcripts in mature effective alfalfa root nodules.}

We performed in situ hybridization to determine the localization of AAT2 transcripts in mature effective alfalfa root

Fig. 1. Detection of AAT2 transcripts in alfalfa nodules by in situ hybridization. A, Bright-field photograph of a toluidine blue-stained longitudinal section of a day 19 effective alfalfa nodule. Zone I (I), invasion zone II (II), interzone II-III (*), nitrogen-fixing zone III (III), and senescent zone IV (IV) are indicated in the box. Abbreviations: $\mathrm{m}$, apical meristem; iz, invasion zone; esz, early symbiotic zone; lsz, late symbiotic zone; sez, early senescent zone; $\mathrm{vb}$, nodule vascular bundle; np, nodule parenchyma; nc, nodule cortex. Bar represents $130 \mu \mathrm{m}$. B, Dark-field photograph of the section shown in (A) hybridized with the AAT2 ${ }^{35}$ S-labeled antisense RNA probe. C, Bright-field photograph of a longitudinal serial section from the same nodule shown in (A) hybridized with the AAT2 ${ }^{35}$ S-labeled sense RNA probe. D, Dark-field photograph of (C). E, Detail of the early symbiotic zone in (A) showing the invasion zone. Arrow indicates first cell layer of the early symbiotic zone adjacent to the invasion zone. Abbreviations: in, infected cells; un, uninfected cells. Bar represents $33 \mu \mathrm{m}$. F, Dark-field photograph of (E) hybridized with the AAT2 ${ }^{35}$ S-labeled antisense RNA probe. G, Detail of the early symbiotic zone shown in $(\mathbf{C})$. H, Dark-field photograph of $(\mathbf{G})$ hybridized with the AAT2 ${ }^{35}$ S-labeled sense RNA probe. 

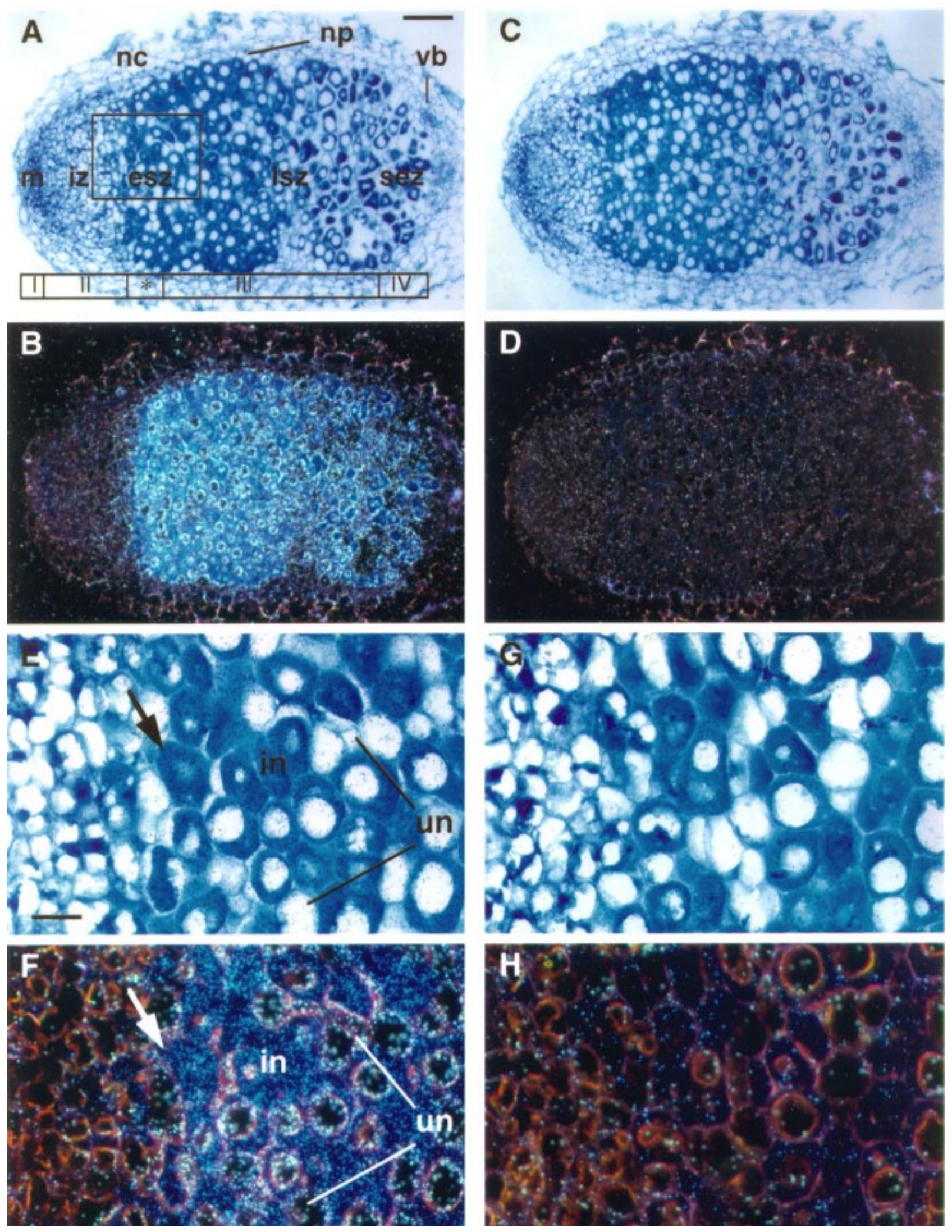
nodules. In a healthy effective nodule, five zones have been identified along the axis of the nodule, based on ultrastructure and function of bacteroids (Hirsch 1992; Vasse et al. 1990). The longitudinal section of a day 19 nodule shown in Figure 1A illustrates the five zones: the apical meristematic zone (zone I); the invasion and prefixing zone (zone II); the amyloplast-rich interzone (zone II-III); the symbiotic and nitrogen-fixing zone (zone III), which can be subdivided into the proximal inefficient nitrogen-fixation region and the distal efficient nitrogen-fixation region; and the early senescent zone (zone IV). The central tissue of the nodule is surrounded by the nodule parenchyma (the inner cortex; van de Wiel et al. 1990) also containing the nodule vascular tissues, and then the nodule outer cortex.

When nodule serial sections were hybridized with AAT2 RNA probes, the antisense probe revealed substantial signals in the section (Fig. 1B), whereas there was no significant signal from the sense probe (Fig. 1C and D). Hybridization of an AAT2 antisense probe to the section resulted in signals that were predominantly localized in the nitrogen-fixing zone (zone III) and the early senescent zone (zone IV), but were not seen in the meristematic zone (zone I), invasion zone (zone II), the nodule parenchyma, nodule vascular bundle, or the outer cortex (Fig. 1B). Higher magnification indicated that AAT2 gene expression was confined principally to the infected cells (Fig. 1E and F) and that AAT2 gene expression in the symbiotic region began in the first cell layer adjacent to the invasion zone, defined as the interzone (zone II-III). Hybridization of an AAT2 sense RNA probe to the serial section showed no significant signal (Fig. $1 \mathrm{G}$ and $\mathrm{H}$ ).

\section{Localization of AAT2 transcripts during effective and plant-gene-controlled ineffective nodule development.}

To investigate the localization of AAT2 transcripts in effective and plant-gene-controlled ineffective nodules, in situ hybridizations were carried out with day 5, 7, 8, 9, 12, and 19 nodules and the results are shown in Figure 2. In day 5 effective nodules, cells in the root cortex have divided, and a relatively broad nodule primordium has formed (Fig. 2A). Hybridization of both effective (Fig. 2B) and ineffective (Fig. $2 \mathrm{~N}$ ) day 5 nodules with an AAT2 antisense probe showed no significant signal. However, day 7 effective nodules showed strong gene expression in infected cells (Fig. 2C and D). At this immature stage, nodules are small bumps on the roots and nitrogenase activity cannot be detected (Gantt et al. 1992). Interestingly, AAT2 expression was also seen in day 7 ineffective nodules to approximately the same extent as in effective nodules although there were fewer infected cells in the ineffective nodules (Fig. $2 \mathrm{O}$ and P). In day 8 and 9 nodules, both effective and ineffective nodules showed strong hybridization signals in the infected cells (Fig. 2E-H and Q-T). Senescence was observed as early as day 9 in ineffective nodules, indicated by a low level of AAT2 transcription in the proximal portion of the symbiotic zone (Fig. 2T). In day 12 nodules we observed an apparent difference in AAT2 gene expression between the effective and ineffective nodules, with fewer silver grains in ineffective nodules throughout the symbiotic zone (Fig. 2U and V), compared with the effective nodules (Fig. 2I and J). This observation suggests that AAT2 gene expression is switched off by at least day 12 in ineffective nodules. This trend was dramatic in day 19 nodules. In con- trast to the day 19 effective nodules (Fig. $2 \mathrm{~K}$ and L), signals were detected in only small, highly localized areas of the invasion zone of the day 19 ineffective nodule (Fig. 2W and X). In some day 19 ineffective nodules drastic senescence occurred in the proximal portion of the symbiotic zone (senescence zone) and relatively high signals were seen in a few cell layers of the interzone, similar to the pattern observed in Figure 2T (data not shown).

\section{Localization of AAT1 transcripts in effective and plant-gene-controlled ineffective nodules.}

To contrast localization of AAT1 transcripts with that of AAT2 transcripts, we performed in situ hybridization with effective and plant-gene-controlled ineffective nodules. As shown in Figure 3, hybridization of an AAT1 antisense RNA probe to longitudinal sections of day 12 effective nodules resulted in localized signals in the invasion zone, the early symbiotic zone, the late symbiotic zone, and the nodule parenchyma (Fig, 3A and B). There was no AAT1 transcript detected in the meristematic zone (Fig. 3B). Hybridization of an AAT1 sense RNA probe to a serial section showed no significant signal (data not shown). A transverse section of the early symbiotic zone from a day 12 effective nodule clearly shows AAT1 transcripts are present in the nodule parenchyma and the central tissue of the nodule (Fig. 3C and D). At higher magnification, the AAT1 signal was observed primarily in uninfected cells, the nodule parenchyma, and cells in the vascular bundle (Fig. 3E and F). As shown in Figure $3 \mathrm{G}$ and $\mathrm{H}$, in day 19 effective nodules AAT1 expression occurs in the nodule parenchyma and uninfected cells of the infection zone and symbiotic zone. In this example, the level of hybridization signal was lower in the infection zone and higher around the root stele than in the day 12 nodule. The pattern and the level of the AAT1 gene expression in day 12 ineffective nodules (Fig. 3I and J) were similar to those of the day 12 effective nodule (Fig. 3A and B).

\section{Localization of AAT2 transcripts in ineffective nodules resulting from infection with ineffective $S$. meliloti.}

We examined nodules elicited by two $S$. meliloti mutants to investigate the effect of nitrogen fixation and intracellular bacterial infection on expression of the AAT2 gene. S. meliloti F642 is defective in dicarboxylic acid transport ( $\operatorname{dctA}$; Yarosh et al. 1989). The nodules elicited by this strain are ineffective, smaller than effective nodules, and have a limited symbiotic zone (Allen et al. 1991). S. meliloti 7154 is defective in acid exopolysaccharide succinylation (exoH; Leigh et al. 1987) and induces very small, tumorlike ineffective nodules. The nodules elicited by the exoH mutant lack intracellular bacteroids and infection threads (Finan et al. 1985; Leigh et al. 1987).

Figure 4 shows the results of in situ hybridization of longitudinal sections of 19-day-old nodules induced by both mutants with an AAT2 antisense RNA probe. As in the plantgene-controlled ineffective nodules, AAT2 transcripts in F642-induced nodules were observed at a low level in infected cells within the symbiotic zone (Fig. 4A and B). Nodules elicited by strain 7154 had meristematic regions spread over a large part of the distal end of the nodule, lacked infected cells, and were covered by a loosely associated cortex (Fig. 4C). No signal from the AAT2 probe was detected in these nodules (Fig. 4D). 
Expression of AAT1 and AAT2 promoter-GUS gene fusions in transgenic alfalfa nodules.

To compare the expression patterns of AAT1 and AAT2, chimeric genes containing 2,100 bp of $5^{\prime}$ upstream sequence from AAT1 and 2,500 bp of $5^{\prime}$ upstream sequence from AAT2 fused to the $\beta$-glucuronidase (GUS) gene were constructed and transferred to alfalfa by Agrobacterium tumefaciensmediated transformation. Histochemical localization of GUS activity was carried out with 13 independent transgenic plants containing the AAT1 promoter construct and 17 independent transgenic plants containing the AAT2 promoter construct. Photomicrographs of the typical staining pattern of sectioned mature nodules are shown in Figure 5. Staining of nodules from plants transformed by the AAT1 promoter-GUS fusion revealed GUS gene expression in nodule vascular bundles, nodule parenchyma, and localized areas in the invasion, early symbiotic, and late symbiotic zones. No staining was seen in the meristem or outer cortex (Fig. 5A). In most plants with the AAT2 promoter construct (pAAT2-1), strong staining occurred in the symbiotic zones of nodules with no staining observed in
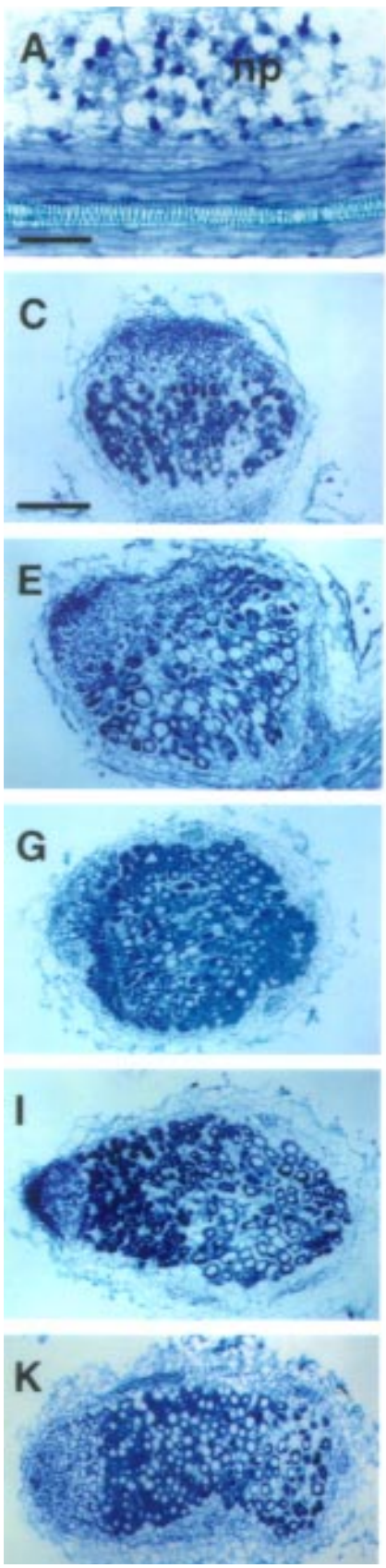
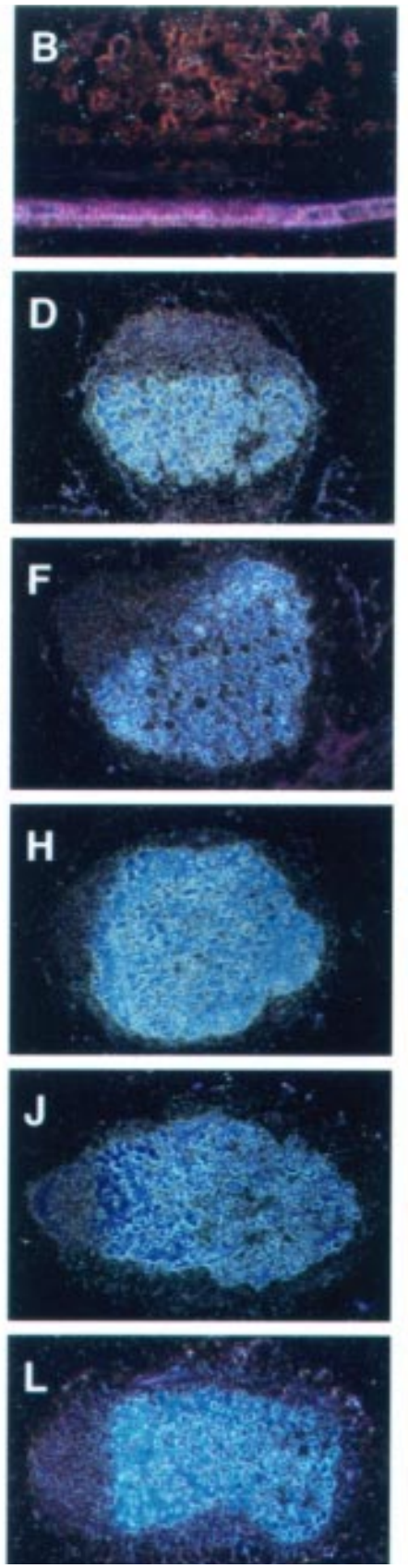
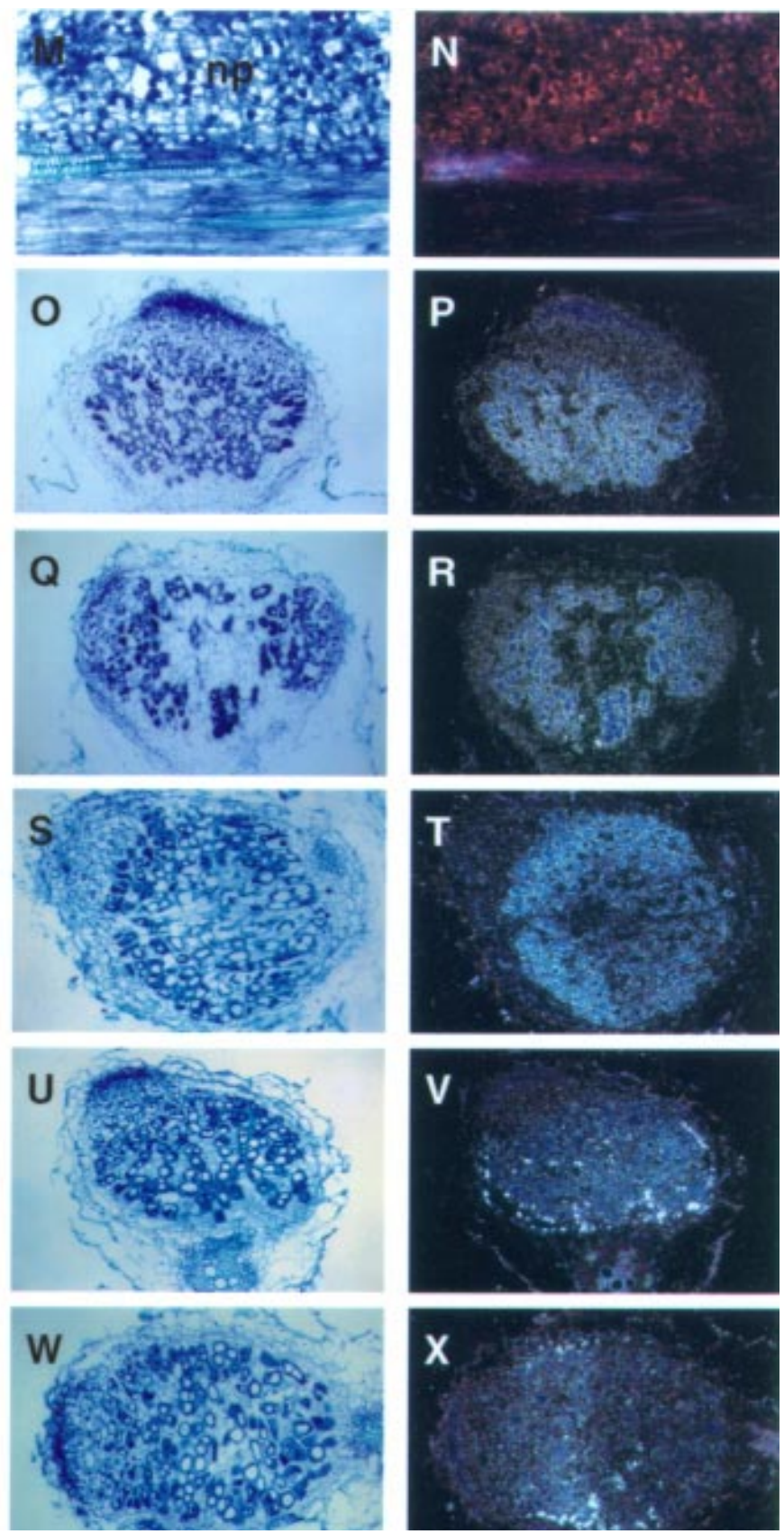

Fig. 2. Localization of AAT2 transcripts in effective and plant-gene-controlled ineffective alfalfa nodules during development. All sections were hybridized with an AAT2 ${ }^{35}$ S-labeled antisense RNA probe and photographed by $(\mathbf{A}, \mathbf{C}, \mathbf{E}, \mathbf{G}, \mathbf{I}, \mathbf{K}, \mathbf{M}, \mathbf{O}, \mathbf{Q}, \mathbf{S}, \mathbf{U}$, and $\mathbf{W})$ bright-field and (B, D, F, H, J, $\mathbf{L}, \mathbf{N}, \mathbf{P}, \mathbf{R}, \mathbf{T}, \mathbf{V}$, and $\mathbf{X}$ ) dark-field exposure. A and $\mathbf{B}$, Alfalfa roots with day 5 effective nodule. np, nodule primordium. Bar represents $60 \mu \mathrm{m}$. $\mathbf{C}$ and $\mathbf{D}$, Day 7 effective nodule. Bar represents $230 \mu \mathrm{m}$. $\mathbf{E}$ and $\mathbf{F}$, Day 8 effective nodule. $\mathbf{G}$ and $\mathbf{H}$, Day 9 effective nodule. I and $\mathbf{J}$, Day 12 effective nodule. $\mathbf{K}$ and $\mathbf{L}$, Day 19 effective nodule. $\mathbf{M}$ and $\mathbf{N}$, Day 5 ineffective nodule. $\mathbf{O}$ and $\mathbf{P}$, Day 7 ineffective nodule. $\mathbf{Q}$ and $\mathbf{R}$, Day 8 ineffective nodule. $\mathbf{S}$ and $\mathbf{T}$, Day 9 ineffective nodule. $\mathbf{U}$ and $\mathbf{V}$, Day 12 ineffective nodule. $\mathbf{W}$ and $\mathbf{X}$, Day 19 ineffective nodule. 

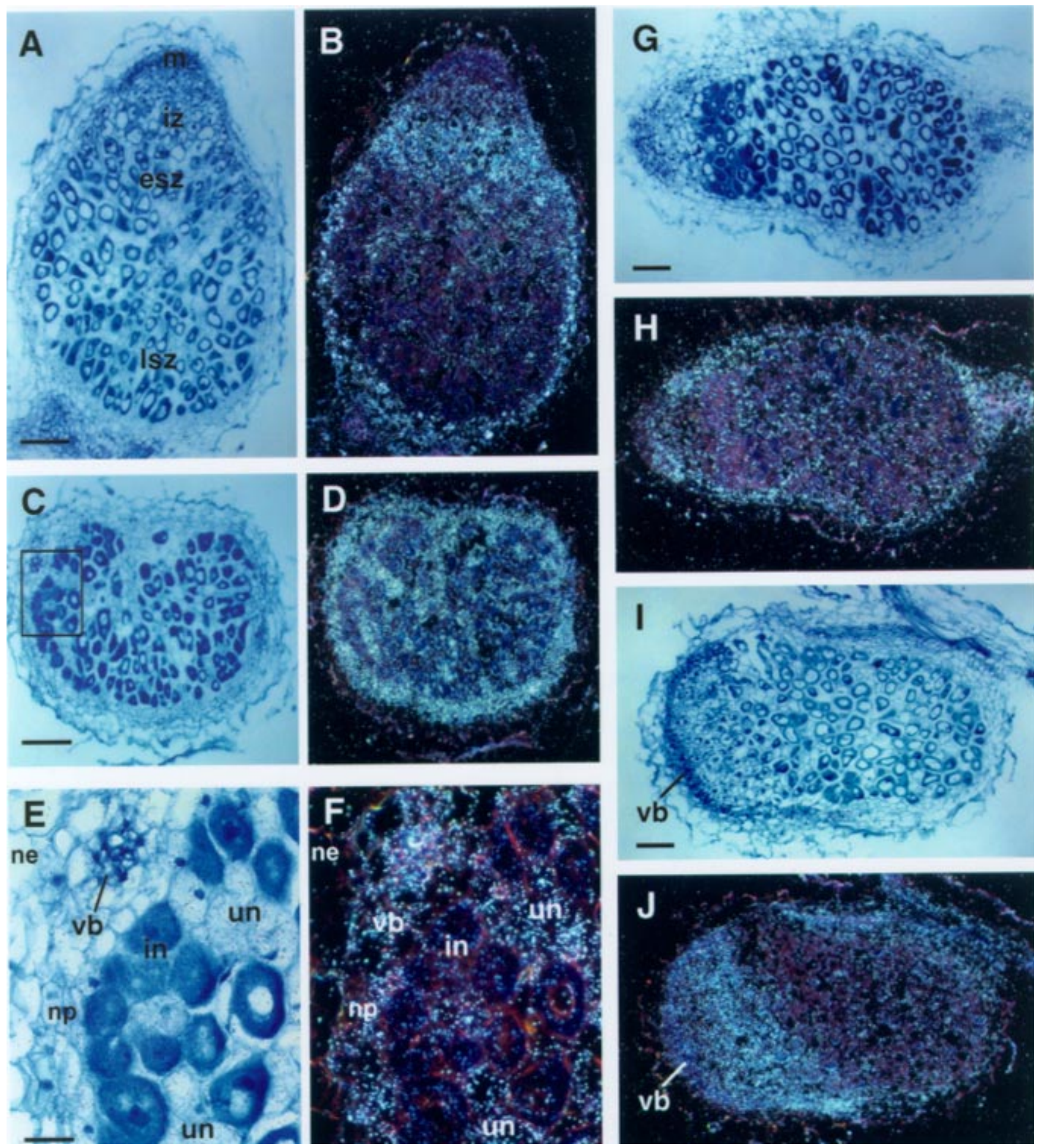

Fig. 3. Detection of AAT1 transcripts in effective and plant-gene-controlled ineffective alfalfa nodules. A, Bright-field photograph of a logitudinal section of a day 12 effective alfalfa nodule. Abbreviations: m, apical meristem; iz, invasion zone; esz, early symbiotic zone; lsz, late symbiotic zone. Bar represents $130 \mu \mathrm{m}$. B, Dark-field photograph of (A) hybridized with an AAT1 ${ }^{35}$ S-labeled antisense RNA probe. C, Bright-field photograph of a transverse section of a day 12 effective alfalfa nodule through the early symbiotic zone. Bar represents $130 \mu \mathrm{m}$. D, Dark-field photograph of (C) hybridized with an AAT1 ${ }^{35}$ S-labeled antisense RNA probe. E, Detail of the area boxed in (A). Abbreviations: ne, nodule cortex; vb, nodule vascular bundle; np, nodule parenchyma; in, infected cells; un, uninfected cells. Bar represents $33 \mu \mathrm{m}$. F, Dark-field photograph of (E) hybridized with an AAT1 ${ }^{35}$ S-labeled antisense RNA probe. G, Bright-field photograph of a longitudinal section of a day 19 effective alfalfa nodule. Meristematic area was not in the plane of the section. H, Dark-field photograph of (G) hybridized with an AAT1 ${ }^{35}$ S-labeled antisense RNA probe. I, Bright-field photograph of a longitudinal section of a day 12 ineffective alfalfa nodule. Bar represents $100 \mu \mathrm{m}$. J, Dark-field photograph of (I) hybridized with AAT1 ${ }^{35} \mathrm{~S}-\mathrm{labeled}$ antisense RNA probe. Meristematic area was not in the plane of the section. Nodule and root vascular bundles are visible at top of figure. Bar represents $100 \mu \mathrm{m}$. 
the meristem, parenchyma, or nodule cortex (Fig. 5B). Staining also occurred in root vascular tissue, leaf veins, and leaf pulvini (data not shown).

To define possible regulatory elements of the AAT2 gene, $5^{\prime}$ deletions of the 2,500-bp region upstream of the translation start codon were fused to the GUS gene as shown in Figure 6, and these chimeric genes were used to transform alfalfa. Histochemical localization of GUS activity was carried out with 10 to 20 independently transformed alfalfa plants for each chimeric gene. The pattern of staining in nodules from plants containing constructs pAAT2-2 though pAAT2-9 was not different from that of nodules expressing the longest $(2,500 \mathrm{bp})$ construct (pAAT2-1). However, the intensity of staining declined with decreased construct size. Medium to light staining was seen in the effective nitrogen-fixing zones of nodules from plants containing the 300-bp construct, pAAT2-9 (Fig. 5C). Staining was completely absent in nodules containing the constructs AAT2-10 and AAT2-11, in which the upstream sequence was shortened to 217 and $147 \mathrm{bp}$, respectively (Figure 5D).

To evaluate further the role of potential cis-acting elements in the AAT2 gene, GUS enzyme activity was measured in nodules exhibiting the typical histochemical staining pattern. Figure 6 shows the number of plants assayed and the mean GUS activity in nodules from plants with each construct relative to the activity in nodules from plants containing the construct with the longest upstream sequence, pAAT2-1. Deletion of sequences upstream of position -1429 (pAAT2-2) decreased GUS activity to $39 \%$ of the mean activity from pAAT2-1. Deleting to position -1051 removed two potential cis-acting elements, CTCTT (-1310) and ATCTTT (-1130), and GUS expression was $46 \%$ of full activity. The next three deletions resulted in upstream sequences of 815, 637, and 520 bp with similar GUS activity of 31 to $32 \%$ of the activity of pAAT2-1. Four potential cis elements were deleted in the -815 construct (CTCTT at positions $-1050,-1036$, and -840 and ATCTTT at -871) and an additional AAAGAT at position -646 was deleted in the 637-bp promoter construct. A marked decrease in activity to 16 and $13 \%$ of full activity occurred in plants containing the deletions ending at positions -410 (pAAT2-7) and -347 (pAAT2-8), respectively. The deleted region between -520 and -347 does not contain either of the potential cis-acting elements. Further deletion of the $5^{\prime}$ region to -300 removes a putative CAAT box $(-334)$ and decreases GUS expression to $7 \%$. GUS activity in the final deletion constructs, -217 and -147 , is at only $1 \%$ of full activity and indistinguishable from background activity. The -217 deletion removed a putative TATA box at position -290 .

\section{DISCUSSION}

The results of the in situ hybridization experiments in this study provide new insights into the regulation of expression of the genes encoding AAT1 and AAT2 in alfalfa. The AAT2
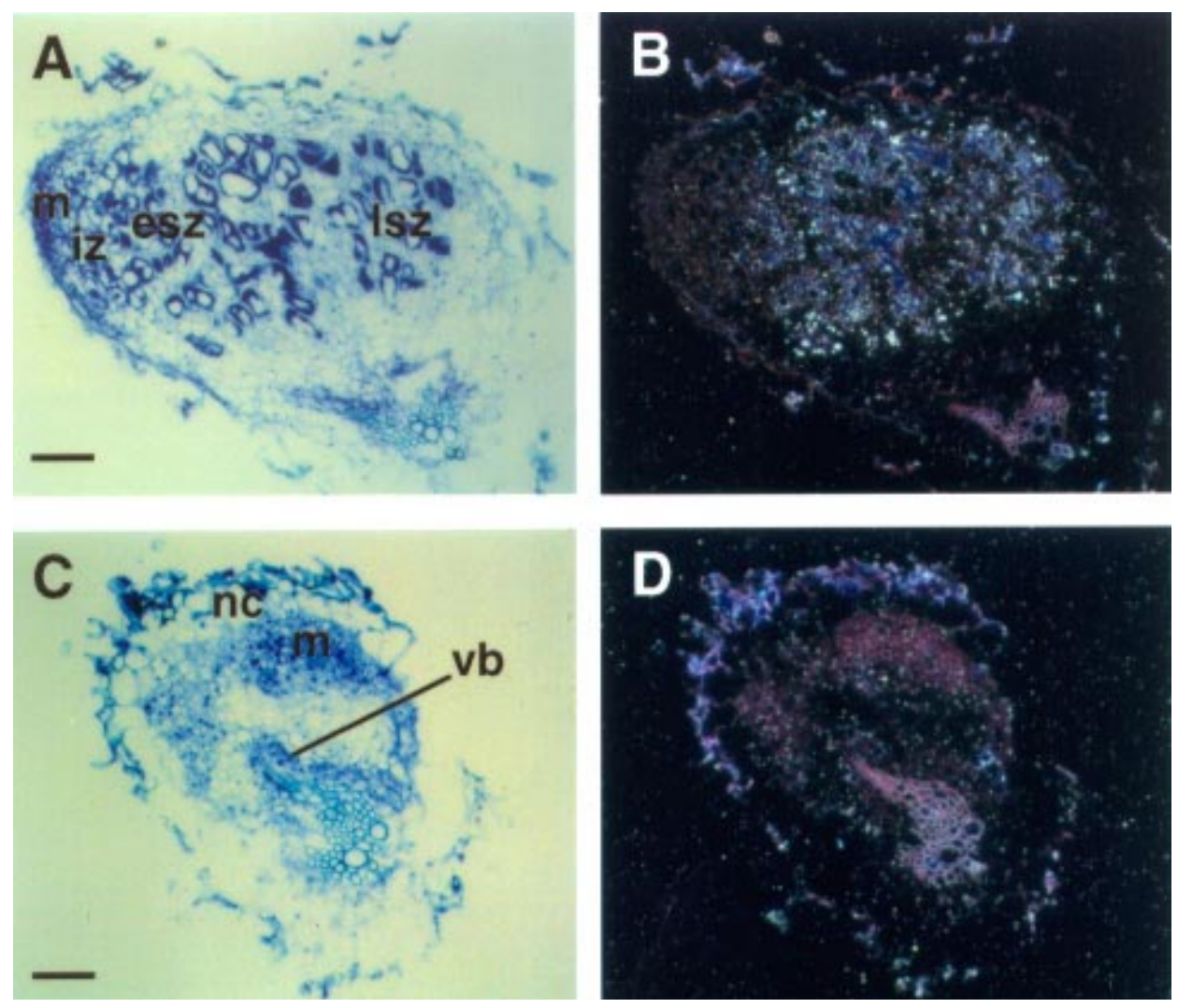

Fig. 4. Detection of AAT2 transcripts in bacterially controlled ineffective alfalfa nodules. A, Bright-field photograph of a logitudinal section of a 19-dayold ineffective alfalfa nodule induced by Sinorhizobium sp. strain F642. Abbreviations: m, apical meristem; iz, invasion zone; esz, early symbiotic zone; lsz, late symbiotic zone. Bar represents $100 \mu \mathrm{m}$. B, Dark-field photograph of (A) hybridized with an AAT2 ${ }^{35}$ S-labeled antisense RNA probe. C, Brightfield photograph of a 19-day-old ineffective alfalfa nodule induced by Sinorhizobium sp. strain 7152. Abbreviations: nc, nodule cortex; m, apical meristem; vb, vascular bundle. Bar represents $100 \mu \mathrm{m}$. D, Dark-field photograph of (C) hybridized with an AAT2 ${ }^{35}$ S-labeled antisense RNA probe. 
gene was shown to be expressed predominately in the infected cells throughout the symbiotic zone of effective alfalfa nodules (Fig. 1). In contrast, AAT1 gene expression was limited to in the invasion zone, the uninfected cells of the symbiotic zone, the nodule parenchyma, and nodule vascular bundles (Fig. 3). AAT2 gene expression was first triggered in the infected cells in the interzone, in which a number of important developmental changes occur. In the interzone, the bacteroids become large and more pleiomorphic, and shift to the nitrogen-fixing type (Vasse et al. 1990) in which the fixK, fixN, and nifA genes are expressed (Soupène et al. 1995). The plant cells in the interzone enlarge and the number of amyloplasts increase. Expression of a number of other late nodulin genes important in nitrogen and carbon metabolism, such as leghemoglobin (de Billy et al. 1991), glutamine synthetase (GS; Temple et al. 1995), glutamate synthase (GOGAT; Trepp et al. 1998), and PEPC (Pathirana et al. 1997), is also initiated in infected cells of the interzone. In situ hybridization showed that strong expression of AAT2 occurred early in nodule development, during day 7 and 8 (Fig. 2), much earlier than the maximum expression of nitrogenase (Gantt et al. 1992), confirming earlier RNA blot analysis of AAT2 expression during development (Gantt et. al. 1992; Gregerson et al. 1994). Previous studies also indicated that AAT2 gene expression was similar in effective and ineffective nodules early in development but that, by day 8 , expression in ineffective nodules was significantly lower than in effective nodules. This was also confirmed by in situ hybridization. Day 8 and 9 ineffective nodules had fewer cells expressing AAT2, compared with ef- fective nodules, and it appeared that the amount of transcript in ineffective nodules was substantially less (Fig. 2). Therefore, initial induction of AAT2 gene expression appears closely correlated to events involved in differentiation of bacteroids. However, expression of AAT2 in root nodules after day 9 appears to be dependent on continued $\mathrm{N}_{2}$ fixation. In day 9,12 , and 17 ineffective nodules in which infected cells are senescing, there is little to no AAT2 expression (Fig. 2). In addition, in nodules incited by $S$. meliloti 7154 in which bacteroid formation does not occur, the AAT2 gene is not expressed (Fig. 4D). These results suggest that the primary role of AAT2 is to assimilate recently fixed ammonia. This role for AAT2 is supported by results from antisense expression of a cDNA of the analogous isozyme from lupin, AAT- $\mathrm{P}_{2}$ (Mett et al. 1996). The cDNA was introduced into transgenic Lotus corniculatus plants in the antisense orientation under the control of a copper-inducible promoter. Upon induction by the addition of copper ions to the nutrient solution, AAT-P2 activity in nodules decreased dramatically and asparagine concentration decreased up to $90 \%$ (Mett et al. 1996). Aspartate is readily converted to asparagine in nodules by asparagine synthase; therefore, a drop in aspartate concentration is reflected in asparagine biosynthesis. There was no change in the expression of AAT-P1, the isoform analogous to the alfalfa AAT1, indicating that this isoform has another, distinct metabolic role in root nodules.

In situ hybridization showed that the majority of AAT1 expression occurred in uninfected cells and localization of AAT1 gene expression within nodules was nearly identical in effec-
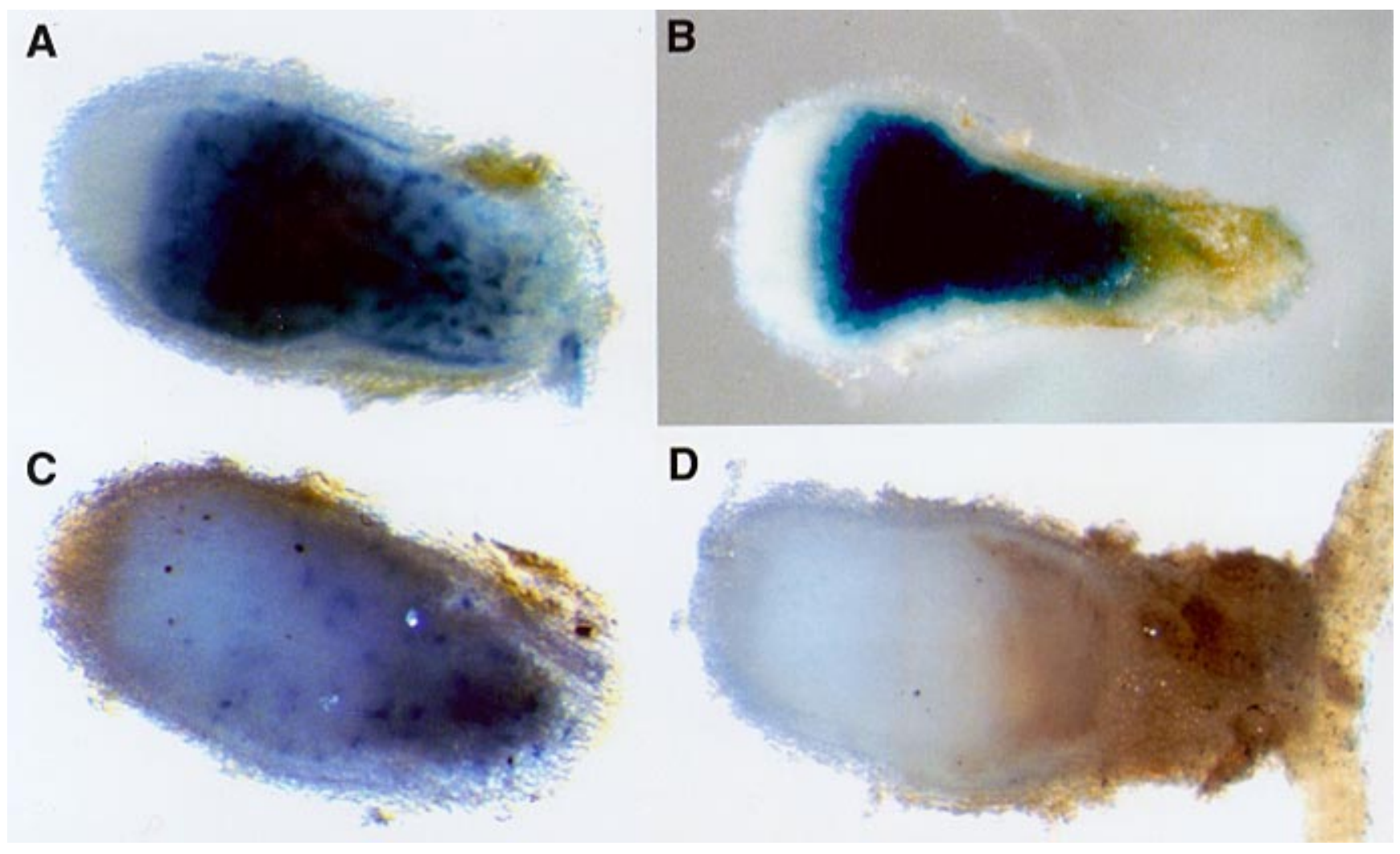

Fig. 5. Histochemical localization of $\beta$-glucuronidase (GUS) reporter gene activity from the AAT1 and AAT2 promoters in 26-day-old alfalfa nodules. Nodule from plant transformed with (A) pAAT1-1, (B) pAAT2-1, (C) pAAT2-9, or (D) pAAT2-10. 
tive and plant-gene-controlled ineffective nodules (Fig. 3). Expression of AAT1 was especially prominent in the nodule parenchyma and vascular bundles. We postulate that a major role for AAT1 in uninfected cells is as a component of the mechanisms contributing to regulation of the oxygen diffusion barrier in nodules. Oxygen concentration is one of the key factors associated with regulation of nitrogenase activity and nodule development. Excess $\mathrm{O}_{2}$ in the symbiotic zone irreversibly inactivates nitrogenase while fixation requires a large flux of oxygen to the bacteroids for production of ATP by oxidative phosphorylation (Soupène et al. 1995). The cells of the nodule parenchyma form a layer of cells that surround the infected host cells and help to provide a low $\mathrm{O}_{2}$ environment in
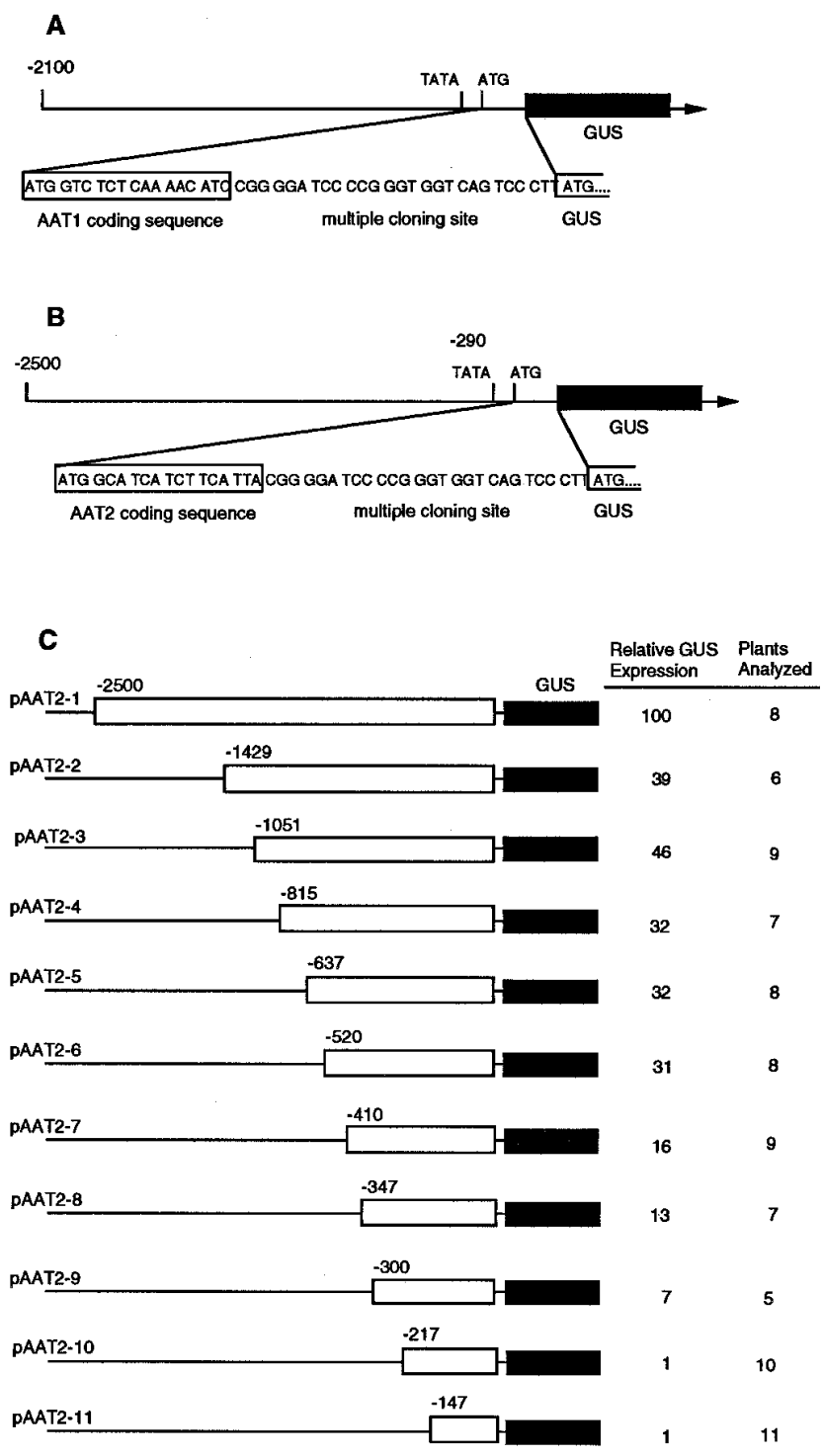

Fig. 6. Diagrams of AAT1 and AAT2 promoter- $\beta$-glucuronidase (GUS) chimeric gene constructs and deletion analysis of the AAT2 promoter. A, AAT1 promoter GUS translational fusion of $2.1 \mathrm{kbp}$ of $5^{\prime}$-flanking sequence to the GUS reporter gene contained in the binary vector pBI101.2. B, AAT2 promoter GUS translational fusion of $2.5 \mathrm{kbp}$ of $5^{\prime}-$ flanking sequence to the GUS reporter gene. C, AAT2 promoter deletions and relative GUS expression. the nodule interior. The barrier must be able to adjust rapidly to changes in the environment and the availability of carbohydrate. A water-filled barrier is predicted by models of gas exchange in legume nodules (Hunt et al. 1988; Sinclair and Goudriaan 1981). A decrease in turgor of parenchyma cells is one means of increasing water content in intercellular spaces and reducing permeability of $\mathrm{O}_{2}$ into the central tissue of the nodule. A number of mechanisms have been proposed to be involved in regulating cell turgor, including modifications in hydroxyproline-rich glycoproteins, shifts in influx and efflux of calcium, modulation of carbon metabolism, and malateinduced changes in $\mathrm{pH}$ and proton extrusion (Hunt and Layzell 1993). Immunogold localization (Robinson et al. 1996) and in situ hybridization analysis (Pathirana et al. 1997) showed that PEPC is present in the alfalfa nodule parenchyma. PEPC activity provides oxaloacetate, which is converted to malate by malate dehydrogenase (MDH) or is transaminated by AAT to form aspartate. The reactions catalyzed by both AAT and MDH are readily reversible. Synthesis of aspartate and/or malate could decrease the osmotic potential of parenchyma cells, resulting in water influx and increased turgor, while catabolism would result in an increase in osmotic potential and water efflux. A mechanism of regulating the $\mathrm{O}_{2}$ diffusion barrier, closely tied to $\mathrm{C}$ and $\mathrm{N}$ metabolism, would allow for rapid and sensitive responses to environmental stresses that reduce carbohydrate supply to nodules. Other proteins found in the nodule parenchyma cells may also have roles in regulating long-term and short-term responses to oxygen (Wycoff et al. 1998).

Results from histochemical staining of nodules from plants containing the AAT1-GUS and AAT2-GUS gene fusion constructs agreed with results from in situ localization studies. The AAT1 5' upstream sequence was active in the nodule periphery, particularly the vascular bundles and parenchyma, with localized activity in the symbiotic zone. The AAT2 5' upstream sequence was active only in the symbiotic zone of the nodules. Interestingly, GUS activity in the symbiotic zone was observed in nodules with AAT2 5' upstream sequences as short as $300 \mathrm{bp}$. No specific sequence motif identified in promoters of other nodule-enhanced genes was shown to be critical for nodule-specific expression of AAT2. However, several motifs are located downstream of putative CAAT $(-334)$ and TATA (-290) boxes close to the translation initiation site. These include two of the six CTCTT motifs $(-46,-16)$ and one of the three AAAGATT motifs in the inverse orientation (-91). In the lupin AAT-P2 promoter, two sequence motifs (AATTATTG at -270 and CTGTGGG at -235 from the initiating ATG) were identified by DNase I footprinting with nodule extracts (V. Mett and P. Reynolds, personal communication). In the alfalfa AAT2 5' upstream sequence, an AATTATTG sequence occurs at -241 and a sequence similar to the second motif, ATGAGGG, at -169 . Because of the proximity of the motifs to the putative TATA and CAAT boxes, their role within the 300-bp promoter sequence cannot be evaluated with the $5^{\prime}$ deletion approach used in this study. A determination of their importance in gene expression will require future DNase I footprinting or a 3 ' promoter deletion study. It is possible that deletion of sequence motifs farther upstream may have affected the level of gene expression because GUS activity decreased with promoter size. Also, one or more of the putative cis-acting elements may play a role in 
the second phase of AAT2 gene expression that is dependent on $\mathrm{N}_{2}$ fixation. We have recently developed a regeneration system for the ineffective alfalfa genotype. Expression of the AAT2 promoter deletion constructs could be analyzed in the ineffective background to determine the effect of the ineffective trait on promoter activity. Finally, we suggest that, due to the relatively high level of expression from the AAT2 promoter in infected cells of root nodules, this promoter may be useful in the expression of chimeric genes for study of the regulation of $\mathrm{N}_{2}$ fixation and for improvement of $\mathrm{N}_{2}$ fixation in legumes.

\section{MATERIALS AND METHODS}

\section{Plant material and bacterial strains.}

Seeds of alfalfa (Medicago sativa L.) cv. Saranac and a single gene recessive genotype ineffective Saranac $\left(\mathrm{in}_{1} \mathrm{Sa}\right)$, which produces early-senescing ineffective nodules (Peterson and Barnes 1981), were obtained from JoAnn F. S. Lamb, (U.S. Department of Agriculture-Agricultural Research Service, St. Paul, MN). The outcrossing tetraploid nature of alfalfa precludes formation of isogenic lines; however, over $90 \%$ of the $i n_{1} \mathrm{Sa}$ genotype is from the Saranac background. Plants were grown in glasshouse sandbenches inoculated with effective Sinorhizobium meliloti 102F51 as previously described (Egli et al. 1989). For localization of AAT1 and AAT2 transcripts in bacterially conditioned ineffective nodules, Saranac seeds were planted in sterilized sand and inoculated with ineffective S. meliloti F642 (Yarosh et al. 1989) or 7154 (Leigh et al. 1987). These strains were generous gifts from Ann Hirsch (University of California, Los Angeles), and Turlough Finan (McMaster University, Hamilton, Ontario, Canada). For all studies, the date that seeds were planted in the sandbench was designated day 0 .

\section{Preparation of RNA probes.}

pBluescript $\mathrm{KS}^{+}$containing the $1.2-\mathrm{kbp}$ alfalfa AAT1 polymerase chain reaction (PCR) product (pAAT1-1; Gregerson et al. 1994) was linearized with EcoRI or SpeI and transcribed in vitro with T7 or T3 RNA polymerase to obtain antisense and sense RNA probes, respectively. To synthesize the AAT2 RNA probes, pBluescript $\mathrm{SK}^{+}$containing the 1.7-kbp alfalfa AAT2 cDNA (pAAT37; Gregerson et al. 1993) was cut with BamHI and transcribed with T3 RNA polymerase to generate an antisense probe or with $X b a \mathrm{I}$ and transcribed from the T7 promoter to generate a sense probe. All probes were labeled with ${ }^{35} \mathrm{~S}$-UTP as described by the manufacturer (Stratagene, La Jolla, CA). Probes were partially degraded to a length of approximately 150 nucleotides by heating at $60^{\circ} \mathrm{C}$ in a $0.06 \mathrm{M}$ $\mathrm{Na}_{2} \mathrm{CO}_{3} / 0.04 \mathrm{M} \mathrm{NaHCO}_{3}$ solution (Cox et al. 1984).

\section{In situ hybridization.}

In situ hybridization was carried out essentially as described by van de Wiel et al. (1990) and Fleming et al. (1993). Tissues were fixed in $4 \%$ paraformaldehyde and $0.25 \%$ glutaraldehyde in $50 \mathrm{mM}$ phosphate buffer, $\mathrm{pH}$ 7.2. The tissues were then rinsed twice in the same buffer, twice in water, and dehydrated in a graded ethanol series. After the absolute ethanol was replaced with xylene, tissues were embedded in Paraplast plus. The embedded tissues were sectioned ( $7 \mu \mathrm{m}$ thick) and affixed to poly-L-lysine-coated slides. Hybridization was performed after Heintzen et al. (1994) in mineral oil maintained at $46^{\circ} \mathrm{C}$ overnight, and the final washing condition was $0.1 \times \mathrm{SSC}(1 \times$ $\mathrm{SSC}$ is $0.15 \mathrm{M} \mathrm{NaCl}, 15 \mathrm{mM}$ sodium citrate) and $1 \mathrm{mM}$ dithiothreitol (DTT) at $50^{\circ} \mathrm{C}$ for $20 \mathrm{~min}$. After 1 to 4 weeks of exposure at $4^{\circ} \mathrm{C}$, the emulsion was developed and sections stained with $0.05 \%$ toluidine blue $\mathrm{O}$ before analysis by lightfield and dark-field microscopy.

\section{Construction of chimeric genes and plant transformation.}

Standard techniques were used for DNA manipulations (Maniatis et al. 1982). A 2.1-kbp fragment of $5^{\prime}$ untranslated sequence from the AAT1 gene and a $2.5-\mathrm{kbp}$ fragment of $5^{\prime}$ untranslated sequence from the AAT2 gene (Gregerson et al. 1994) were used for promoter analysis. These DNA fragments were generated by PCR amplification of the respective promoter regions with a proofreading thermostable DNA polymerase (PfuI; Stratagene, La Jolla, CA). The primers contained restriction enzyme recognition sequences at the $5^{\prime}$ and $3^{\prime}$ ends (HindIII and BamHI, respectively). PCR products were then subcloned into pBI221 (Jefferson 1987), producing promoter-GUS fusions plasmids pAAT1GUS and pAAT2GUS. A set of deletions were obtained by digesting pAAT2GUS with SalI, filling in the recessed end with $\alpha$-thiodNTPs with Klenow DNA polymerase and subsequently digesting with $X b a$ I. Clones were sequenced to determine the exact length of each promoter fragment. The AAT2 promoterGUS cassettes were cut from these plasmids with HindIII and SacI and ligated into pBI101.2 (Jefferson 1987) cut with the same enzymes. These plasmids were designated pAAT2-1, pAAT2-2, pAAT2-3, pAAT2-4, pAAT2-5, pAAT2-6, pAAT27 , and pAAT2-11, and contained $-2500,-1429,-1051,-815$, $-637,-520,-410$, and -147 nucleotides upstream from the ATG of the AAT2 coding sequence, respectively (Fig. 6). An additional three vectors, pAAT2-8, pAAT2-9, and pAAT2-10, with $-347,-300$, and -217 bp of upstream sequence, respectively, were constructed by PCR with sequence-specific primers that included a HindIII site on the $5^{\prime}$ end and BamHI site on the $3^{\prime}$ end for cloning into pBI101.2. Sequence analyses of these chimeric genes demonstrated that each insert was cloned correctly and that the insertion created translational fusion products.

The promoter-GUS constructs were introduced into Agrobacterium tumefaciens LB4404 by electroporation. Transgenic Medicago sativa cv. Regen SY plants (Bingham 1991) were obtained essentially as described by Austin et al. (1995). Verification that plants were transgenic was obtained by PCR analysis of DNA extracted from regenerated plants. Regenerated plants were maintained as vegetative cuttings in vermiculite. Nodules were elicited by inoculation with $S$. meliloti 102F51. Nodule tissues were collected 12 to 26 days after inoculation for histochemical detection and enzymatic assays of GUS activity.

\section{Analysis of GUS activity.}

Detection of GUS activity in nodules was performed by modifications of the procedure described by Jefferson (1987). Briefly, for efficient uptake of the staining solution, nodules were cut in half by hand and vacuum infiltrated for $15 \mathrm{~min}$ followed by incubation for 2 to $18 \mathrm{~h}$ at $37^{\circ} \mathrm{C}$ in $1 \mathrm{mg}$ of 5 bromo-4-chloro-3-indolyl $\beta$-D-glucuronic acid (X-gluc) per $\mathrm{ml}, 0.1 \mathrm{M}$ phosphate buffer, $\mathrm{pH} 7.5,0.5 \mathrm{mM} \mathrm{K}_{3}[\mathrm{Fe}(\mathrm{CN}) 6], 0.5$ 
$\left.\mathrm{mM} \mathrm{K}_{4[} \mathrm{Fe}(\mathrm{CN})_{6}\right], 10 \mathrm{mM}$ EDTA, and $0.1 \%$ Triton $\mathrm{X}-100$. The GUS-stained tissues were fixed in paraformaldehyde/glutaraldehyde solution, rinsed in water, and stored in $70 \%$ ethanol until they were photographed.

GUS activity was determined essentially as described by Jefferson (1987). Nodules were collected and homogenized in extraction buffer. The supernatant after centrifugation was used to quantitate GUS activity with 4-methylumbelliferyl $\beta$ D-glucuronic acid (4-MUG) as a substrate. Tissues from regenerated, nontransformed plants were used to quantitate background activity. Enzyme activity was measured with a TKO-100 Fluorometer (Hoeffer Scientific, San Francisco, CA). Protein concentration was determined with the BioRad Protein Assay (BioRad Laboratories, Hercules, CA).

\section{Image processing.}

Photographic images were captured to Photoshop software (Adobe Systems, Mountain View, CA) on a Macintosh computer. Composite figures were arranged with PowerPoint (Microsoft, Redmond, WA) and printed with a Tektronix Phaser IIsdx dye sublimation printer (Tektronix, Wilsonville, $\mathrm{OR})$ at the University of Minnesota Imaging Center.

\section{ACKNOWLEDGMENTS}

This work was supported in part by United States Department of Agriculture, National Research Initiative grant no. 97-35305-4628. This paper is a joint contribution from the Plant Science Research Unit, USDA, Agricultural Research Service, and the Minnesota Agricultural Experiment Station (Paper No. 21751, Scientific Journal Series). Mention of a trademark, proprietary of the product, or vendor does not constitute a guarantee or warranty of the product by the USDA, and does not imply its approval to the exclusion of other products and vendors that might also be suitable.

\section{LITERATURE CITED}

Allen, T., Raja, S., and Dunn, K. 1991. Cells expressing ENOD2 show differential spatial organization during the development of alfalfa root nodules. Mol. Plant-Microbe Interact. 4:139-146.

Austin, S., Bingham, E. T., Mathews, D. E., Shahan, M. N., Will, J., and Burgess, R. R. 1995. Production and field performance of transgenic alfalfa (Medicago sativa $\mathrm{L}$.) expressing $\alpha$-amylase and manganesedependent lignin peroxidase. Euphytica 85:381-393.

Bingham, E. T. 1991. Registration of alfalfa hybrid Regen-SY germplasm for tissue culture and transformation research. Crop Sci. 31: 1098

Boland, M. J., Hanks, J. F., Reynolds, P. H. S., Blevins, D. G., Tolbert, N. E., and Schubert, K. R. 1982. Subcellular organisation of ureide biogenesis from glycolytic intermediates and ammonium in nitrogen fixing soybean nodules. Planta 155:45-51.

Cox, K. H., Deleon, D. V., Angerer, L. M., and Angerer, R. C. 1984. Detection of mRNA in sea urchin embryos by in situ hybridization using asymmetric RNA probes. Dev. Biol. 101:485-502.

de Billy, F., Barker, D. G., Gallusci, P., and Truchet, G. 1991. Leghaemoglobin gene transcription is triggered in a single cell layer in the indeterminate nitrogen-fixing root nodule of alfalfa. Plant J. 1:27-35.

Egli, M. A., Griffith, S. M., Miller, S. S., Anderson, M. P., and Vance, C. P. 1989. Nitrogen assimilating enzyme activities and enzyme protein during development and senescence of effective and plant genecontrolled ineffective alfalfa nodules. Plant Physiol. 91:898-904.

Farnham, M. W., Griffith, S. M., Miller, S. S., and Vance, C. P. 1990a. Aspartate aminotransferase in alfalfa root nodules. III. Genotypic and tissue expression of aspartate aminotransferase in alfalfa and other species. Plant Physiol. 94:1634-1640.

Farnham, M. W., Miller, S. S., Griffith, S. M., and Vance, C. P. 1990b. Aspartate aminotransferase in alfalfa. II. Immunological distinction between two forms of the enzyme. Plant Physiol. 93:603-610.
Finan, T. M., Hirsch, A. M., Leigh, J. A., Johansen, E., Kuldau, G. A., Deegan, S., Walker, G. C., and Signer, E. R. 1985. Symbiotic mutants of Rhizobium meliloti that uncouple plant from bacterial differentiation. Cell 40:869-877.

Fleming, A. J., Mandel, T., Roth, I., and Kuhlemeier, C. 1993. The patterns of gene expression in the tomato apical meristem. Plant Cell 5: 297-309.

Gantt, J. S., Larson, R. J., Farnham, M. W., Pathirana, S. M., Miller, S. S., and Vance, C. P. 1992. Aspartate aminotransferase in effective and ineffective alfalfa nodules: Cloning of a cDNA and determination of enzyme activity, protein, and mRNA levels. Plant Physiol. 98:868878.

Gregerson, R. G., Miller, S. S., Petrowski, M., Gantt, J. S., and Vance, C. P. 1994. Genomic structure, expression and evolution of the alfalfa aspartate aminotransferase genes. Plant Mol. Biol. 25:387-399.

Gregerson, R. G., Petrowski, M., Larson, R. L., Gantt, J. S., and Vance, C. P. 1993. Molecular analysis of allelic polymorphism at the AAT2 locus of alfalfa. Mol. Gen. Genet. 241:124-128.

Griffith, S. M., and Vance, C. P. 1989. Aspartate aminotransferase in alfalfa root nodules. I. Purification and partial characterization. Plant Physiol. 90:1622-1629.

Hatch, M. D., and Mau, S. L. 1973. Activity, location and role of aspartate aminotransferase and alanine aminotransferase isoenzymes in leaves with $\mathrm{C}_{4}$ pathway photosynthesis. Arch. Biochem. Biophys. 156:195-206.

Heintzen, C., Melzer, S., Fischer, R., Kappeler, S., Apel, K., and Staiger, D. 1994. A light- and temperature-entrained circadian clock controls expression of transcripts encoding nuclear proteins with homology to RNA-binding proteins in meristematic tissue. Plant J. 5:799-813.

Hirsch, A. M. 1992. Developmental biology of legume nodulation. New Phytol. 122:211-237.

Hunt, S., Gaito, S. T., and Layzell, D. B. 1988. Model of gas exchange and diffusion in legume nodules. II. Characterisation of the diffusion barrier and estimation of the concentrations of $\mathrm{CO}_{2}, \mathrm{H}_{2}$, and $\mathrm{N}_{2}$ in the infected cells. Planta 173:128-141.

Hunt, S., and Layzell, D. B. 1993. Gas exchange of legume nodules and the regulation of nitrogenase activity. Annu. Rev. Plant Physiol. Plant Mol. Biol. 44:483-511.

Jefferson, R. A. 1987. Assaying chimeric genes in plants: The GUS gene fusion system. Plant Mol. Biol. Rep. 5:387-405.

Jørgensen, J.-E., Stougaard, J., and Marcker, K. A. 1991. A twocomponent nodule-specific enhancer in the soybean $\mathrm{N} 23$ gene promoter. Plant Cell 3:819-827.

Lauridsen, P., Franssen, H., Stougaard, J., Bisseling, T., and Marcker, K. A. 1993. Conserved regulation of the soybean early nodulin ENOD2 gene promoter in determinate and indeterminate transgenic root nodules. Plant J. 3:483-492.

Leigh, J. A., Reed, J. W., Hanks, J. F., Hirsch, A. M., and Walker, G. C. 1987. Rhizobium meliloti mutants that fail to succinylate their calcofluor-binding exopolysaccharide are defective in nodule invasion. Cell 51:579-587.

Liu, K. D. F., and Huang, A. H. C. 1977. Subcellular localization and developmental changes of aspartate- $\alpha$-ketoglutarate transaminase isozymes in the cotyledons of cucumber seedlings. Plant Physiol. 59: 777-782.

Maniatis, T. A., Fritsch, E. F., and Sambrook, J. 1982. Molecular Cloning: A Laboratory Manual. Cold Spring Harbor Laboratory, Cold Spring Harbor, NY.

Mett, V. L., Podivinsky, E., Tennant, A. M., Lochhead, L. P., Jones, W. T., and Reynolds, P. H. S. 1996. A system for tissue-specific coppercontrollable gene expression in transgenic plants: Nodule specific antisense of aspartate aminotransferase- $\mathrm{P}_{2}$. Transgenic Res. 5:105-113.

Metz, B. A., Welters, P., Hoffman, H. J., Jensen, E. Ø., Schell, J., and de Bruijn, F. J. 1988. Primary structure and promoter analysis of leghemoglobin genes of the stem-nodulated tropical legume Sesbania rostrata: Conserved coding sequences, cis elements, and trans-acting factors. Mol. Gen. Genet. 214:181-191.

Numazawa, T., Yamada, S., Hase, T., and Sugiyama, T. 1989. Aspartate aminotransferase from Panicum maximum Jacq. var. trichoglume Eyles, a $\mathrm{C}_{4}$ plant: Purification, molecular properties, and preparation of antibody. Arch. Biochem. Biophys. 270:313-319.

Pathirana, M. S., Samac, D. A., Roeven, R., Yoshioka, H., Vance, C. P., and Gantt, J. S. 1997. Analyses of phosphoenolpyruvate carboxylase gene structure and expression in alfalfa nodules. Plant J. 12:293-304. 
Peterson, M. A., and Barnes, D. K. 1981. Inheritance of ineffective nodulation and non-nodulation traits in alfalfa. Crop Sci. 21:611-616.

Robinson, D. L., Kahn, M. L., and Vance, C. P. 1994. Cellular localization of nodule-enhanced aspartate aminotransferase in Medicago sativa L. Planta 192:202-210.

Robinson, D. L., Pathirana, S. M., Gantt, J. S., and Vance, C. P. 1996. Immunogold localization of nodule-enhanced phosphoenolpyruvate carboxylase in alfalfa. Plant Cell Environ. 19:602-608.

Ryan, E., and Fottrell, P. F. 1974. Subcellular localization of enzymes involved in the assimilation of ammonia by soybean root nodules. Phytochemistry 13:2647-2652.

Sandal, N. N., Bojsen, K., and Marcker, K. A. 1987. A small family of nodule specific genes from soybean. Nucleic Acids Res. 15:15071519.

Scandalios, J. G., Sorenson, J. C., and Ott, L. A. 1975. Genetic control and intracellular localization of glutamate oxaloacetic transaminase in maize. Biochem. Genet. 13:759-769.

Schubert, K. R. 1986. Products of biological nitrogen fixation in higher plants: Synthesis, transport, and metabolism. Annu. Rev. Plant Physiol. 37:539-574.

Schultz, C. J., and Coruzzi, G. M. 1995. The aspartate aminotransferase gene family of Arabidopsis encodes isoenzymes localized to three distinct subcellular compartments. Plant J. 7:61-75.

Sinclair, T. R., and Goudriaan, J. 1981. Physical and morphological constraints on transport in nodules. Plant Physiol. 67:143-145.

Soupène, E., Foussard, M., Boistard, P., Truchet, G., and Batut, J. 1995. Oxygen as a key developmental regulator of Rhizobium meliloti $\mathrm{N}_{2}$ fixation gene expression within the alfalfa root nodule. Proc. Natl. Acad. Sci. USA 92:3759-3763.

Stougaard, J., Sandal, N. N., Grøn, A., Kühle, A., and Marcker, K. A. 1987. $5^{\prime}$ analysis of the soybean leghaemoglobin $l b c_{3}$ gene: Regulatory elements required for promoter activity and organ specificity. EMBO J. 6:3565-3569.

Taniguchi, M., and Sugiyama, T. 1990. Aspartate aminotransferase from Eleusine coracana, a $\mathrm{C}_{4}$ plant: Purification, characterization and preparation of antibody. Arch. Biochem. Biophys. 282:427-432.

Temple, S. J., Heard, J., Ganter, G., Dunn, K., and Sengupta-Gopalan, C. 1995. Characterization of a nodule-enhanced glutamine synthetase from alfalfa: Nucleotide sequence, in situ localization, and transcript analysis. Mol. Plant-Microbe Interact. 8:218-227.

Trepp, G. B., van de Mortel, M., Yoshioka, H., Miller, S. S., Samac, D. A., Gantt, J. S., and Vance, C. P. Localization and regulation of the NADH-dependent glutamate synthase in alfalfa root nodules. Plant Physiol. (In press.)

Turano, F. J., Wilson, B. J., and Matthews, B. F. 1991. Rapid purification and thermostability of the cytoplasmic aspartate aminotransferase from carrot suspension cultures. Plant Physiol. 97:606-612.

Udvardi, M. K., and Kahn, M. L. 1992. Isolation and analysis of a cDNA clone that encodes an alfalfa (Medicago sativa) aspartate aminotransferase. Mol. Gen. Genet. 231:97-105.

van de Wiel, C., Scheres, B., Franssen, H., van Lierop, M.-J., van Lammeren, A., van Kammen, A., and Bisseling, T. 1990. The early nodulin transcript ENOD2 is located in the nodule parenchyma (inner cortex) of pea and soybean root nodules. EMBO J. 9:1-7.

Vance, C. P., and Johnson, L. E. B. 1983. Plant determined ineffective nodules in alfalfa (Medicago sativa): Structural and biochemical comparisons. Can. J. Bot. 61:93-106.

Vance, C. P., Miller, S. S., Gregerson, R. G., Samac, D. A., Robinson, D. L., and Gantt, J. S. 1995. Alfalfa NADH-dependent glutamate synthase: Structure of the gene and importance in symbiotic $\mathrm{N}_{2}$ fixation. Plant J. 8:345-358.

Vasse, J., de Billy, F., Camut, S., and Truchet, G. 1990. Correlation between ultrastructure differentiation of bacteroids and nitrogen fixation in alfalfa nodules. J. Bacteriol. 172:4295-4306.

Wadsworth, G. J., Marmaras, S. M., and Matthews, B. F. 1993. Isolation and characterization of a soybean cDNA clone encoding the plastid form of aspartate aminotransferase. Plant Mol. Biol. 21:993-1009.

Wallsgrove, R. M., Keys, A. J., Lea, P. J., and Miflin, B. J. 1983. Photosynthesis, photorespiration and nitrogen metabolism. Plant Cell Environ. 6:301-309.

Weeden, N. F., and Marx, G. A. 1984. Chromosomal locations of twelve isozyme loci in Pisum sativum. J. Hered. 75:365-370.

Wycoff, K. L., Hunt, S., Gonzales, M. B., VandenBosch, K. A., Layzell, D. B. and Hirsch, A. M. 1998. Effects of oxygen on nodule physiology and expression of nodulins in alfalfa. Plant Physiol. 117:385-395.

Yarosh, O. K., Charles, T. C., and Finan, T. M. 1989. Analysis of $\mathrm{C}_{4}$ dicarboxylate transport genes in Rhizobium meliloti. Mol. Microbiol. 3:813-823. 